Etikonomi

Volume 16 (1), April 2017

P-ISSN: 1412-8969; E-ISSN: 2461-0771

Page $53-70$

\title{
PERFORMANCE OF DEPOSITOR FUND: A LESSON FROM INDONESIAN ISLAMIC BANKING INDUSTRY
}

\author{
Sayakhmad Olimov, Abdul Hamid, M. Arief Mufraini \\ UIN Syarif Hidayatullah Jakarta
}

mr.saidahmad84@mail.ru, abdul.hamid@uinjkt.ac.id, arief.mufraini@uinjkt.ac.id

\begin{abstract}
.
The objective of study is to analyze the performance of Depositor Fund in the operation of Islamic bank as an alternative banking sector in financial market based on the profit and loss mode of financing in the case of Indonesia. The research methodology is quantitative analysis based on the Multiple Regression. In the study secondary data is used and were collected from Annual Report of Islamic Banks. The sample of study is the bank, which is selected from 36 samples of Islamic Commercial Banks relates to non-probability purposive sampling method as a statistical research techniques. The result of study showed that the performance of Depositor Fund in the operation of Islamic banks has negative proficiency and otherwise the Islamic banks have weaknesses capability to improve the high ratio of increasing productivity Depositor Fund based on the financial ratio factors, which are analysed.
\end{abstract}

Keywords: Islamic bank, performance, financial ratio, depositor fund, CAMEL's model.

\begin{abstract}
Abstrak.
Tujuan studi ini adalah untuk menganalisis kinerja Dana Deposan dalam operasi bank syariah sebagai sektor perbankan alternatif dalam pasar kenangan berdasarkan laba rugi modus pembiayaan dalam kasus Indonesia. Metodologi penelitian ini adalah analisis kuantitatif berdasarkan pada Model Regresi Berganda. Dalam penelitian data sekunder yang digunakan dan dikumpulkan dari Laporan Tabunan Bank Islam. Sampel penelitian adalab bank yang dipilib dari 36 sampel Bank Islam Komersial berkaitan dengan non-probabilitas metode purposive sampling sebagai teknik penelitian statistik. Hasil penelitian menunjukean bahwa kinerja Dana Deposan dalam operasi bank syariah memiliki kemampuan negatif dan sebaliknya bank syariah memiliki kelemahan kemampuan untuk meningkatkan rasio tinggi meningkatkan produktivitas Deposan Dana berdasarkan faktor-faktor rasio keuangan yang dianalisis.
\end{abstract}

Kata Kunci: bank Islam, kinerja, rasio keuangan, dana deposan, model CAMEL

Received: January 5, 2017 Revised: February 15, 2017; Approved: March 14, 2017 
Performance of Depositor Funds ..........

Sayakhmad Olimov, Abdul Hamid, M Arief Mufraini

\section{INTRODUCTION}

Indonesia is the largest community Muslim in the world, and is one of the optimist on implementing Islamic economy perspective after the previous global financial crisis which has made the attention to turn on the Islamic financial model, and in general the Islamic banking system (Rahajeng, 2013). There are some engines of growth, which is trigger in particular of such as industry, especially the big Muslim population, need of costumers, banking regulations, alternative education program and authorities with Islamic economics researchers solution (Ismal, 2011). The contribution of Islamic banks in Indonesia towards national economic growth remains dependent to large extent on how they are able to operate effectively, either in offering attractive product and services or other in playing a constructive as social welfare role (Adnan, 2003). According to the Law of Islamic banking of Indonesia No. 21 of 2008 social-religious functions of Islamic bank which is as a unique characteristic of Islamic bank must be as strong attraction for the community financial services to the customers.

Despite having the world's largest Muslim population and being a dynamic emerging economy, Indonesia plays only a very minor role in the global Islamic banking industry. With nearly 85 percent of the 250 million people living in Indonesia, the market share of sharia banking is remarkably low. As an illustration, with a figure of USD \$24 billion, Indonesia's Islamic banks only held 5 percent of the country's total banking assets in 2015 year. On the other hand, according to the Indonesian Islamic financial scholars the growth of Islamic banking system in Indonesia faces challenges that must to be solved (Ismal, 2011). Development of Islamic banks of Indonesia faces to an essential problem that have not constructed a program of comprehensive development by rethinking the nature of money in Islam in terms of the intrinsic relationship between money as a moral and social necessity linked endogenously with real economic activities (Choudhury, 2007). Practically, in Indonesia Islamic banks in their business get started with capital from the founders, in addition get funds from a Depositor Funds, the profit-sharing will be given to the founders and customers over the invested funds to banks, from the profit-sharing of each set aside sharing into zakat (Hasbi and Haruman, 2011).

The analysis of operations Islamic bank should be addressed appropriately to deposit transactions which the real of growth capital ratio Islamic banks and its provides a high benefits in growing national economy, and also for the Moslem society in general terms becomes the reasons of reducing inflation, stabilizing the economy, catalyzing real 
sector development, reducing unemployment, promoting justice and equality, as well as improving the social-welfare generally. Thus, the case relates to analyze the performance process of increasing productivity of depositor Fund at operation Islamic Banks in Indonesia a country as the one of the largest and this focuses in determining the positive performance Depositor Fund and finding the alternative solution for development Islamic banking in Indonesia.

Essentially, increasing productivity Depositor Fund in Islamic banks from depositors significantly important, due to the source of financial strength Islamic banks is deposit money and also the capacity of banking operation increase profit for shareholders. The existing body of knowledge demonstrate that research on Islamic banking deposits is still scarce. During a review of the existing literature concerning Islamic banking operations it was found that only a handful of sources discuss the real issues related to Islamic banking deposits and suggests practical mechanisms to overcome the problems. Moreover, the Islamic bankers also support the argument that the behaviour of Islamic banking depositors is similar that of conventional banking depositors, as can be seen in their presentations at some of the professional seminars and conferences organised by the industry-related institutions. Based on the trend of the existing literature, this research concludes that the area of deposits in Islamic banking is considered as a settled issue by the Islamic bankers, and also by most researchers who have an interest in the Islamic banking industry, as the Islamic banks continue carry on their normal business without any attempt to solve the real problem embedded within it.

Despite of increasing Depositor Fund based on the profit and loss mode of financing in the operation of Islamic banking sector in Indonesia, the results of previous empirical researchers showed that Islamic banks face to many challenges in performance Depositor Fund which is identified such as; short terms saving and investment deposits, similar transactions conventional banking deposits money costumers, lack of costumers in understanding quality product and services Islamic bank, low of demand deposit costumers, conflict in distribution profit between participants and also unauthorized Islamic deposit insurance are the most serious problem that still unresolved. Essentially, the lack of profit and loss sharing (PLS) in increasing productivity Depositor Fund is a global challenge affecting Islamic banks worldwide, and accordingly the causes of these problems are human resource management challenges, agency problem in capital trust corporation in partnership, high risk of equity based transactions, and risk of moral hazard effected to 
Performance of Depositor Funds ..........

Sayakhmad Olimov, Abdul Hamid, M Arief Mufraini

growth slowly Islamic banking market share in the modernization of financial and money markets as a real sector.

The objectives of study is to analyze the performance of Depositor Fund in the operation of Islamic banking system as an alternative banking sector in financial market based on the profit and loss modes of financing in the case of Indonesia and to evaluate empirically assessment the capability of Islamic banks performance based on the financial ratio factors that consist of capital asset, management quality, operations income and expensive, nonperforming finance, and liabilities under principles of sharia compliant requirements.

The same as most of the Moslem countries, Indonesia has progressive Islamic banking industry which relies on the performance of the real sector (Ismal, 2011). Historical progress of Islamic banking in Indonesia, formally began with the Workshop MUI on banking in 1990, which was subsequently followed by the issuance of Banking Act No.7/1992 about banking which accommodate banks activities with profit-sharing principle. In 2008 the Government issued Islamic Banking Law No.21/2008, that expected to provide a more solid legal basis and greater opportunities in the development of Islamic Banking in Indonesia so that equal and parallel to the conventional banks (Hasbi and Haruman, 2011; Sari, et.al., 2016). In Indonesia, the development of Islamic banking is based on two considerations. Firstly, there is a large niche market in Indonesia, which refuses to be serviced and catered by conventional banks, and secondly, the Islamic banking is an alternative system, which could be implemented as one of the bankingrestructuring programs initiated by the Indonesian government. The development of Islamic banks in Indonesia has showed significant progress, but their role in the economy is still small. It is envisioned that the industry could achieve a significant contribution and play a greater role in national economy. To support these efforts, the central bank has devised a long-term plan for the next decade, based upon three phases of implementation. One of the strategy is by spin-off policy. Al Arif (2014) stated that spin-off policy give a third party funds difference between pre and post spin-off in Islamic banking.

Practically, the development of the Indonesian Islamic banking industry is conducted under the dual banking system (conventional and Islamic banking systems) in the micro and macro framework, namely the Architecture of the Indonesian banking (AIB) and the Architecture of the Indonesian Financial System (AIFS) (Ismal, 2009). Islamic finance is a form of banking or banking activity that is consistent with the principles of 
sharia (Islamic law). For example, the prohibition of interest (riba) payments and excessive uncertainty (gharar) or gambling (maysir). Based on the review of Islamic Banking Act No.21, 2008, the Indonesian Islamic Banking Model is classified into three levels. Namely, Sharia (Islamic) Commercial Bank (ICB) is a Sharia (Islamic) Bank providing services in the transaction of payments, Sharia (Islamic) Rural Bank (IRB) is a Sharia (Islamic) Bank which do not provide services in the transaction of payment, and Sharia (Islamic) Business Unit (IBU) is a working unit of the Conventional Commercial Bank (CCB) head office functioning as head office of offices or units conducting business activities based on the Sharia Principle (Act No. 21/2008, Article 1).

Ismal (2011) describes that in Indonesia, there is a dynamic model of Islamic banking which is mostly relates to liquidity management called Islamic Banking Dynamic Model of Indonesia (ISLAMI) to manage liquidity in Islamic banking industry. He has argument that ISLAMI model captures four essential sectors to successfully manage liquidity represented by four dynamic models. The first sector is depositors represented by liability model to analyze the liquidity behavior of depositors. The second sector is Islamic banks and entrepreneurs represented by asset model to inform how Islamic banks manage depositor's funds. The third sector is bank's liquidity reserves represented by bank's liquidity reserves model to analyze the management of liquidity reserves. And the finally is banking regulator (Central Bank) represented by Islamic monetary operation model to assess the central bank's policies to manage liquidity (Ismal, 2011).

Finally, to improve and foster the development of the industry, Central Bank of Indonesia has set up long-term Islamic banking development policies, namely a blueprint of the Indonesian Islamic banking industry that encloses sixth initiative to be implemented in the ten years of the blueprint program (2005-2015). Accordingly in Indonesia, the development of Islamic banking is based on two considerations. Firstly, there is a large niche market in Indonesia, which refuses to be serviced and catered by conventional banks, because of Islamic principles. The introduction of an Islamic banking system will assist the banking system as a whole to effectively mobilize funds in this market. Secondly, the Islamic banking is an alternative system, which could be implemented as one of the banking-restructuring programs initiated by the Indonesian government.

Like interest-based conventional banks, the main function of Islamic banks is to mobilize savings and provide financial support to the entrepreneurs. Yet there are differences in techniques applied in the process of savings mobilization and financing 
Performance of Depositor Funds ...........

Sayakhmad Olimov, Abdul Hamid, M Arief Mufraini

investment by the two banking systems. Depositors receive interest in a predetermined rate for their deposits made with an interest-based bank. Similarly, the investors are to pay a predetermined rate of interest to the bank. The technique, thus, involves each and every partner in the transaction process (i.e. the depositor, the investor and the bank) with the element of interest. Islamic bank, on the other hand, neither pays nor receives interest from any of its transactions thereby saving everybody from the curse of interest. Islam disapproves hoarding of savings and encourages its productive investment (Chapra, 1985). It mobilizes savings of the common people in line with Islamic Shariah and techniques employed by Islamic banks for saving mobilization are following that According to the scholars Hasbi and Haruman (2011), analyzed that in Indonesia Islamic banks in their business get started with capital from the founders, in addition get funds from a Depositor Funds, the profit-sharing will be given to the founders and customers over the invested funds to banks, from the profit-sharing of each set aside sharing into zakat.

Deposits from savers are an important source of financial strength for the Islamic banks and the bank raise funds generally based on Amanah or Wadhiah arrangements, on Mudharabah and on Wakalah for Fund Management. The only thing that is known with certainty is that the depositor will share proportionately in the profits and losses of the lending or investing activities of the bank. Despite all positive banking indicators above, the Indonesian Islamic banking is like other financial institutions. It faces various banking risks such as liquidity risk, exchange rate risk, market risk, reputation risk, deposit withdrawal risk, credits risk. Amongst all risks, deposit withdrawal risk is the most important one to be anticipated. Nonetheless, not many studies had been done with respect to this risk in the case of Indonesian Islamic banking industry. Particularly, the study that focuses on the psychological aspects of depositors towards their deposit withdrawal behavior is never found in the literature so far (Abduh and Sukmana, 2011). The general study on liquidity risk management done by Ismal (2009), addressed several potential problems that might cause deposit withdrawals in Islamic banks.

The protection of Islamic deposits and investment accounts under a deposit insurance system has generated much discussion in the Islamic finance fraternity as to whether or not the products, especially the latter, could, in the event of a bank failure, be covered under the system from the Islamic law (Shari'ah) viewpoint. In contrast to Islamic deposits, whose amounts are principal guaranteed, investment accounts are non-principal 
guaranteed products. Investment accounts also commonly form the bulk of customer funds held at institutions offering Islamic financial services.

Performance of the banks is measured at two levels, one is at the management and regulatory level of the banks and another is at external rating agencies. Purpose of regulatory and supervisory rating systems is to measure the bank performance at internal level and its compliance with regulatory requirements to keep the bank on right track (Babar and Zeb, 2011). The CAMEL methodology was originally adopted by North American bank regulators to evaluate the financial and managerial soundness of U.S. commercial lending institutions. The CAMEL reviews and rates five areas of financial and managerial performance: Capital adequacy, Asset quality, Management, Earnings, and Liquidity. Based on the conceptual framework of the original CAMEL, ACCION International developed its own instrument. Although the ACCION CAMEL reviews the same five areas as the original CAMEL, the indicators and ratings used by ACCION reflect the unique challenges and conditions facing the micro finance industry. The MFI is required to gather the following information for a CAMEL examination: (1) financial statements; (2) budgets and cash flow projections; (3) portfolio aging schedules; (4) funding sources; (5) information about the board of directors; (6) operations/staffing; and (7) macroeconomic information. Financial statements form the basis of the CAMEL's quantitative analysis.

According the financial scholars El-Hawary et.al. (2004), the CAMEL Rating System cannot qualify as an adequate and appropriate system in interpreting the accurate performance of the Islamic banking system since there is no single component in it to measure the Shariah compatibility of the functions if judged through the CAMEL rating system, the health of an Islamic bank would be visualized but its Shariah compatibility would not be determined. Moreover, the present framework of CAMEL rating may not include all aspects of Islamic banking if it is to be as per the explanation and spirit of Shariah (Sarker, 2010). He argues that though all features of CAMELS are not repugnant or contradictory to the Shariah stance, there should be some separate provisions to make it conducive and proper to analyse the whole operation of the Islamic banks. But on the other hand, the one of Indonesian Islamic financial scholar Muljawan (2009) suggested that practically, Islamic banking could use the CAMELS rating system when assessing the soundness of the Islamic banks, but there are some difference approaches which would be on several aspects like: (1) the agency role in the capital assessment, (2) value added 
Performance of Depositor Funds ..........

Sayakhmad Olimov, Abdul Hamid, M Arief Mufraini

distribution, (3) identification of risks which do not appear in the conventional banks, and (4) the incorporation of the Islamic values and norms which particularly emphasis professionalism, competence to promote conducive and friendly atmosphere in the organization and other Islamic values like environment orientation besides transaction ally sharia compliance (Muljawan, 2009).

It seems from the foregoing discussion that CAMELS Rating System cannot qualify as an adequate and appropriate system in interpreting the accurate performance of the Islamic banking system since there is no single component in it to measure the Sharia compatibility of the functions of a bank in an Islamic framework. CAMELS rating system has been viewed in light of the principles and practices of Islamic banking. One of the most important concerns of regulators and supervisors of Islamic banks is how to apply internationally recognized standards to these institutions while, simultaneously, enabling them to operate in conformity with the Shariah. In view of the special nature of investment deposits and the risk faced by the assets of Islamic banks, application of the international capital adequacy standards to Islamic banks has become a challenging task (Chapra and Khan, 2000). The Islamic banking industry might also use the same CAMELS framework when designing an appropriate rating system for Islamic banking, but with some improvement and modifications to adopt the typical differences in the Islamic banking operations. Like in conventional system, the rating system designed is used as one significant base in conducting supervisory actions.

\section{METHOD}

The research methodology in this study is a scientific quantitative analysis based on the Regression Analysis Model which is definitely in statistical modeling and a process of estimating the influence of independent variables to the dependent variable. The dependent variables represent the output or outcome whose variation is being studied. The independent variables represent inputs or causes, i.e. potential reasons for variation. Models test or explain the effects that the independent variables have on the dependent variables. An independent variable is one that influences the dependent variable in either a positive or negative way. There are five independent variables in the research: 1. Capital Adequacy Ratio (CAR). 2. Return on Assets (ROA). 3. Non-Performing Financing (NPF). 4. Operating Expense to Operating Income (OEOI). 5. Financing to Deposit Ratio (FDR) which those of Operational Research Variables. A dependent variable is the variable of 
primary interest to researcher. The researcher's goal is to understand and describe the dependent variable, or to explain its variability, or predict it. Dependent variables in this research is the Depositor Fund of Islamic Banks. The ratios would compared with Depositor Fund as a reflect level of public trust for Islamic banking industry in Indonesia. If the ratios indicate a good performance, it sign that the bank can manage all of the aspect well and supposed to increase depositor fund in Islamic bank and has positive performance.

The model that used in this paper is:

$$
Y=\alpha+\beta_{1} C A R+\beta_{2} R O A+\beta_{3} N P F+\beta_{4} O E O I+\beta_{5} F D R+\varepsilon
$$

Where: $\mathrm{Y}$ is depositor fund; CAR is capital adequacy ratio; ROA is return on asset; NPF is non performing financing; OEOI is operational expenditure operational income (operational efficiency ratio); FDR is financing to deposit ratio.

The data collection in this study is used the secondary data that is collected from Annual Report of Islamic Banks from Central Bank of Indonesia. The framework of the study that is based upon secondary data using monthly data over the 5 financial periods of 2010 to 2014 consists of 60 months. Findings of our research are complex in nature but our secondary data will help us to achieve this objective. The electronic search engine is the main source in this study is used from University electronic library, Google search, electronic books, journals, and also from other academic materials.

\section{RESULT AND DISCUSSION}

Normality test is done in order to see the level of normality of data used, whether it is normal distributed or not. The level of normality of data is highly crutial because if data is normally distributed, it means the data can represent the population. Normality data test aims to test whether the dependent variable and independent variables both have a normal distribution or not in the regression model. Based on the assessment analyses of distribution variables in the Normality Test which are dependent variable and independent variables both have a normal distribution and therefore in can be concluded that the result of test is free of problem in normality distribution.

Multicollinerity test aims to test whether in regression model is found a correlation among independent variables. The way to know either there is symptom of Multicollinerity or not is by seeing the value of Variance Inflation Factor (VIF) and tolerance, if the value of VIF is less than 10 and value of tolerance is more than 0.1 , thus, it 
Performance of Depositor Funds

Sayakhmad Olimov, Abdul Hamid, M Arief Mufraini

is stated that Multicollinerity does not occur. The Multicollinerity test can be seen in the Table 1.

Table 1. The Result of Multicollinerity Test

\begin{tabular}{cccc}
\hline & \multicolumn{2}{c}{ Collinearity Statistics } & \\
\hline Variable & Tolerance & VIF & Conclusion \\
\hline CAR & 1.228 & 0.815 & No Multicollinerity \\
ROA & 1.852 & 0.540 & No Multicollinerity \\
NPF & 1.554 & 0.656 & No Multicollinerity \\
OEOI & 1.708 & 0.585 & No Multicollinerity \\
FDR & 1.243 & 0.804 & No Multicollinerity \\
\hline
\end{tabular}

Based on the result Table 1, the value of VIF for CAR is 1.199, the value of VIF for ROA is 1.703, the value of VIF for NPF is 1.486, the value of VIF for OEOI is 1.647, and the value of VIF for FDR is 1.253. It can be seen that the value of Variance Inflation Factor for all independent variables is less than 10. The value of Tolerance for CAR is 8.34 , the value of Tolerance for ROA is 5.87 , and the value of Tolerance for NPF is 6.73 , the value of Tolerance for OEOI is 6.07, and the value of Tolerance for FDR is 7.98. The value of Tolerance for all independent variables is also bigger than 0,1 . Therefore, it can be concluded that the Multicollinerity does not occur on CAR, ROA, NPF, OEOI, and FDR independent variables.

Heteroscedasticity test is used to indicate in a regression model whether there is variance inequality of residual on one observation to other observations. Heteroscedasticity can be indicated by seeing the resulted scatterplot. The result of Heteroscedasticity test can be seen in the following graph:

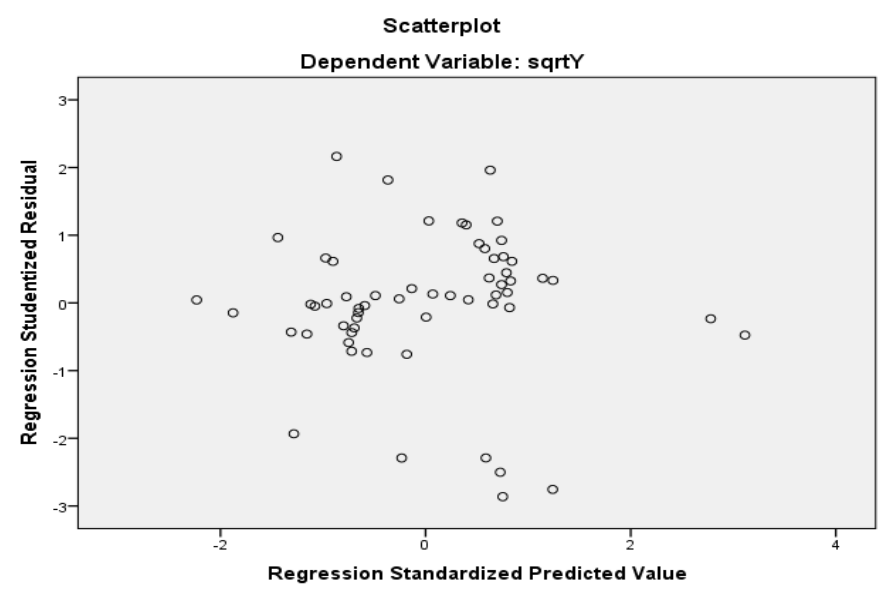

Figure 1. The Result of Heteroscedasticity Test 
From the scatterplot Figure 1, it is appeared that the data points are spread out, not only gather above or below $\mathrm{Y}$ axis. Then the distribution does not form a wavy pattern. Then, glejser test can also be used for ensuring the Heteroscedasticity does not occur. Accordingly, if the significance value among independent variables with residual is more than 0,05 , then, Heteroscedasticity does not occur.

Autocorrelation test is used to detect the internal correlation among the groups of a series observation arrange in a series of place and time A good regression model does not have autocorrelation problem. The basic of decision making in this test are based on Durbin-Watson Test and Run Test, which can be seen in the Table 2.

Table 2. The Result of Autocorrelation Test

\begin{tabular}{cccccc}
\multicolumn{6}{c}{ Model Summary b } \\
\hline Model & $\mathbf{R}$ & R Square & $\begin{array}{c}\text { Adjusted R } \\
\text { Square }\end{array}$ & $\begin{array}{c}\text { Std. Error of the } \\
\text { Estimate }\end{array}$ & Durbin-Watson \\
\hline 1 & $.428^{a}$ & .183 & .107 & 87.10382 & 1.613 \\
\hline \multicolumn{4}{c}{ a. Predictors: (Constant), FDR, ROE, CAR, NPF, OEOI } \\
b. Dependent Variable: Y
\end{tabular}

Testing method that usually used is by using Durbin-Watson Test (DW test) with testing criteria as follows:

1. $\mathrm{Du}<\mathrm{dw}<4-\mathrm{du}$, thus Ho is accepted, autocorrelation does not occur.

2. $\mathrm{dw}<\mathrm{dl}$ or $\mathrm{dw}>4-\mathrm{dl}$, thus Ho is rejected, autocorrelation occurs.

3. $\mathrm{Dl}<\mathrm{dw}<\mathrm{du}$ or $4-\mathrm{du}<\mathrm{dw}<4-\mathrm{dl}$, uncertainty occurs.

Based on the Table 4.5: it can be seen that the significance value of DW is 1.613 and the value of $\mathrm{d}$ count is placed between Du formula and $1.7-(\mathrm{Du}<\mathrm{Dw}<4-\mathrm{Du})$, which is Ho is accepted, and therefore, it can be concluded that in the result of test autocorrelation does not occur and free from problem.

A statistical hypothesis is a hypothesis testable on the basis of observing a process that is modeled via a set of random. In statistic hypothesis test is a method of statistical inference. A t-test is most commonly applied when the test statistic would follow a normal distribution if the value of a scaling term in the test statistic were known. This test is used to know whether independent variables partially influence towards dependent variable, or not, by assuming other independent variables are constant. 
Performance of Depositor Funds ..........

Sayakhmad Olimov, Abdul Hamid, M Arief Mufraini

Table 3. The Result of t-Test

\begin{tabular}{|c|c|c|c|c|c|c|c|}
\hline \multirow[b]{2}{*}{ Model } & \multicolumn{2}{|c|}{$\begin{array}{c}\text { Unstandardized } \\
\text { Coefficients }\end{array}$} & \multirow{2}{*}{$\begin{array}{c}\text { Standardized } \\
\text { Coefficients } \\
\text { Beta } \\
\end{array}$} & \multirow[b]{2}{*}{$\mathrm{t}$} & \multirow[b]{2}{*}{ Sig. } & \multicolumn{2}{|c|}{ Collinearity Statistics } \\
\hline & $\mathrm{B}$ & Std. Error & & & & Tolerance & VIF \\
\hline (Constant) & -364.205 & 1038.979 & & -.351 & .727 & & \\
\hline CAR & 83.164 & 548.882 & .020 & .152 & .880 & .834 & 1.199 \\
\hline $\mathrm{ROE}$ & -997.628 & 605.263 & -.265 & -1.648 & .105 & .587 & 1.703 \\
\hline NPF & -696.500 & 714.087 & -.146 & -.975 & .334 & .673 & 1.486 \\
\hline OEOI & -344.095 & 640.599 & -.085 & -.537 & .593 & .607 & 1.647 \\
\hline FDR & 1207.384 & 553.404 & .300 & 2.182 & .034 & .798 & 1.253 \\
\hline
\end{tabular}

a. Dependent Variable: Y

Based on the Table 3, it can be acquired that the variable of CAR $\left(\mathrm{X}_{1}\right)$ has not significance value of 8.80 which is greater than $0,05(8.80>0,05)$ and also has t count of 1.52 which is less than $t$ table of $1,688(1.52<1,688)$. Thus, it means $\mathrm{H} 0$ is not rejected and $\mathrm{Ha}$ is not accepted because of $\mathrm{t}$ count is less than $\mathrm{t}$ table and the value of significance is greater than $\alpha(0,05)$, it can be concluded that the variable of CAR partially doesn't influence towards Depositor Fund. The cause of the insignificant impact of Islamic banking depositor funds in Indonesia is not usually maintain financial liquidity, apart from Bank Indonesia to follow the reference to the amount of the provisions of CAR, as well as an decrease in public confidence in the Islamic banking to increased capital of the company and followed the principles of good risk management.

The variable of $\mathrm{ROA}\left(\mathrm{X}_{2}\right)$ has not significance value of 10.5 which is greater than $0,05(10.5>0,05)$ and also has $t$ count of -1.648 which is less than $t$ table of $1,688(-$ $1.648<1,688)$. Thus, it means $\mathrm{H}_{0}$ is not rejected and $\mathrm{Ha}$ is not accepted because of $\mathrm{t}$ count is less than t table and the value of significance is greater than $\alpha(0,05)$, it can be concluded that the variable of ROA partially doesn't influence towards Depositor Fund. The cause of the lack of significant effect at ROA of Islamic banking of depositor funs may be due to income earned is not optimal because Islamic banking is still in the stage of expansion and expanding office network, the affect the profits that are used to reproduce a form of property assets, information systems, HR training etc.

The variable of NPF $\left(\mathrm{X}_{3}\right)$ has not significance value of 33.4 which is greater than $0,05(33.4>0,05)$ and also has $t$ count of -9.75 which is greater than $t$ table of $1,688(-$ $9.75>1,688)$. Thus, it means $\mathrm{H}_{0}$ is not rejected and $\mathrm{Ha}$ is not accepted because of $\mathrm{t}$ count is less than $t$ table and the value of significance is greater than $\alpha(0,05)$, it can be concluded that the variable of NPF partially doesn't influence towards Depositor Fund. The cause of insignificant non-performing financing to depositor funds ratio of Islamic banking may be 
the reason that all procedures and regulations in the management of credit is not doing well and the funds does not provided to the customer actually selected with strict quality.

The variable of OEOI $\left(\mathrm{X}_{4}\right)$ has not significance value of 59.3 which is greater than $0,05(59.3>0,05)$ and also has $t$ count of -5.37 which is greater than $t$ table of 1,688 ($.537>1,688)$. Thus, it means $\mathrm{H}_{0}$ is not rejected and $\mathrm{Ha}$ is not accepted because of $\mathrm{t}$ count is less than $t$ table and the value of significance is greater than $\alpha(0,05)$, it can be concluded that the variable of OEOI partially doesn't influence towards Depositor Fund. This could be because the low motivation management and stakeholder to manage its operations efficiently, this cannot be done because the size of Islamic banking company that is still relatively small so that all operational activities of banking can be monitored well and they although cannot identify potential inefficiencies quickly and directly carried out repairs.

The variable of FDR $\left(X_{5}\right)$ has significance value of 03.4 which is less than 0,05 $(03.4>0,05)$ and also has $t$ count of 2.182 which is less than $t$ table of $1,688(2.182>$ 1,688). Thus, it means $H_{0}$ is rejected and $\mathrm{Ha}$ is accepted because of $\mathrm{t}$ count is greater than $\mathrm{t}$ table and the value of significance is greater than $\alpha(0,05)$, it can be concluded that the variable of FDR partially influence towards Depositor Fund. Cause of significant effect to depositor funds may be due to the bank tries to maintain liquidity and stability of the banking healthiness from the effect of external factors that potentially interfere to Islamic banking operations.

F- Test is done in order to know the influence of independent variables towards dependent variable simultaneously.

Table 4. The Result of F-Test

\begin{tabular}{clccccc}
\hline & & Sum of & & & \\
& Model & Squares & df & Mean Square & F & Sig. \\
\hline 1 & Regression & 91635.544 & 5 & 18327.109 & 2.416 & $.048^{\mathrm{b}}$ \\
& Residual & 409702.077 & 54 & 7587.075 & & \\
& Total & 501337.621 & 59 & & & \\
\hline
\end{tabular}

a. Dependent Variable: Y

b. Predictors: CAR (X1), ROA (X2), NPF (X3), OEOI (X4), and FDR (X5)

Based on the Table 4, it is known that the value of level significance is 0,048 which is less than significance level of $0,05(0,048<0,05)$ and otherwise the score of $\mathrm{F}$ count is 2.416 which is greater than F table of $2,16(2.416>2,16)$. Finally, the result test 
Performance of Depositor Funds ..........

Sayakhmad Olimov, Abdul Hamid, M Arief Mufraini

showed that the independent variables such as CAR $\left(\mathrm{X}_{1}\right), \operatorname{ROA}\left(\mathrm{X}_{2}\right), \operatorname{NPF}\left(\mathrm{X}_{3}\right)$, OEOI $\left(\mathrm{X}_{4}\right)$, and FDR $\left(\mathrm{X}_{5}\right)$ simultaneously influence towards Depositor Fund.

Technique of analysis that has been used in this research is the multiple linier regression. Analysis of multiple linier regression is used as the analysis tools of statistics because this research has been designed to research the variables which have influence among independent variables and dependent variable. Regression equation can be determined by seeing the Table 3. From Table 3, thus the regression model reached is as follows:

Depositor Fund $=\mathbf{- 3 6 4 . 2 0 5}+\beta_{1}$ 83.164 CAR $+\beta_{2} \mathbf{- 9 9 7 . 6 2 8 R O A}+\beta_{3} \mathbf{- 6 9 6 . 5 0 0 ~ N P F}$

$$
+\beta_{4}-\mathbf{3 4 4 . 0 9 5} \text { OEOI }+\beta_{5} \text { 1207.384 FDR }+\mathrm{e}
$$

Where the regression equations show that the Constanta of Depositor Funds amount of - 364.205 is negative. It means if independent variables such as CAR, ROA, NPF, OEOI and FDR assumed to be constant inexistence of independent variables such the variables of CAR, ROA, NPF, OEOI, and FDR. Then, the dependent variable which is assumed that the Islamic banking Depositor Fund tends to decrease. The regression equality shows that the regression coefficient of variable Capital Adequacy Ratio (CAR) is negative. The ratios would compared with Depositor Funds as a reflect level of public trust for Islamic banking industry in Indonesia. If the ratios indicate a good performance, it sign that the bank can manage all of the aspect well and supposed to increase depositor funds in Islamic bank. The output is determined as Capital Adequacy Ratio (CAR), the ability of banks offset a decline in assets due to losses on bank assets using its own capital. The greater this ratio, it means the better bank's capital adequacy ratio.

The regression equality shows that the regression coefficient of variable Return on Assets (ROA) is negative. The Return on Assets (ROA), which measure the effectiveness of the company in utilizing all resources in order to measure the ability to generate profits. The higher this ratio, it means the more effective use of assets to obtain income and the better performance of the bank. The regression equality shows that the regression coefficient of variable Non-Performing Financing (NPF) is negative. The Non-Performing Financing (NPF), which measures the level of bad debt that had to be reserved. The smaller this ratio, it means that the better performance of the bank. The regression equality shows that the regression coefficient of variable Operating Expense to Operating Income (OEOI) is negative. 
The Operating Expense to Operating Income (OEOI), which measures the level of efficiency and distribution of the bank in conducting its operations. The smaller this ratio, it means that the better performance of the bank. The regression equality shows that the regression coefficient of variable Operating Expense to Operating Income (OEOI) is positive. The Financing to Deposit Ratio (FDR) is ability to repay the bank withdrawals by customers with relying on loans as a source of liquidity.

Coefficient of determination $\left(\mathrm{R}^{2}\right)$ is basically used to measure regarding how far the ability of model can define variance of dependent variable. Based on the Table 5, it shows that Adj. $\mathrm{R}^{2}$ is $.428^{a}$ or $42.8 \%$. This means that $42.8 \%$ as the value of dependent variable, which is Depositor Fund how is influenced by independent variables such as CAR, ROA, NPF, OEOI, and FDR based on the Classical Assumption Test and Regression Analysis Model, which are analyzed.

Table 5. The Result of Determinant Coefficient

\begin{tabular}{lrrrrr}
\hline Model & R & R Square & $\begin{array}{c}\text { Adjusted R } \\
\text { Square }\end{array}$ & $\begin{array}{c}\text { Std. Error of the } \\
\text { Estimate }\end{array}$ & Durbin-Watson \\
\hline 1 & $.428^{a}$ & .183 & .107 & 87.10382 & 1.613 \\
\hline
\end{tabular}

a. Predictors: (Constant), FDR, ROE, CAR, NPF, OEOI

b. Dependent Variable: Y

Usman (2015) found that the religious norms had an affect on the decision in using the Islamic banks. Sari, et.al (2015) shown that there are several factors that influence people to become Islamic bank customer, such as: psychological, social, personal, economic, and cultural. Besides that factor, Islamic banks should increase the promotion cost in order to increase the deposit funds. Al Arif (2010) found that promotion cost had an affect to deposit funds in the Islamic banks. Rusydiana (2016) suggested that the Islamic banks should do several strategies to resolve the problems in Islamic banking industry. Another problem that Islamic banks in Indonesia should consider is efficiency, especially post spin-off policy. Al Arif (2015) found that there are an efficiency declining in Islamic banks after spin-off period.

\section{CONCLUSION}

Based on the research result analysis study can be concluded that Islamic banking capital ratio in Indonesia get starts from Depositor Fund, and practically, Islamic banks performance Depositor Fund productivity is based on the Mudharabah and Wadiah transactions for saving and investing money depositors. Based on the result study in 
Performance of Depositor Funds ...........

Sayakhmad Olimov, Abdul Hamid, M Arief Mufraini

comparison with previous researches, as a researcher would like to suggest that it must be researched in the future and find out the alternatives solution for development Islamic Banking System in Indonesia following as: First, one of the serious problem in this sector is a high risk of transactions banking that Islamic banks face in their operations for increasing productivity of developing high ratio of capital asset and return to investment, especially in positive performance of depositor fund. Second, further research of Human Resource Management in development Islamic banking in Indonesia has more strategically values. Third, further research should be focused the issue of Strategic Marketing Management Islamic Bank product and services which are consider customer creation value, brand evolution and awareness, real customer needs analysis, and creating benefits of product and services for public trust should be the reasons of development Islamic banking industry.

\section{REFERENCES}

Adnan, M.A. (2003). Development of Islamic Economy Movement in Indonesia: A Review. Proceding Paper. Presented in the 60th Anniversary Islamic University of Indonesia.

Abduh, M. \& R. Sukmana. (2011). Depositor Behavior in Indonesia Islamic Banking: Does Crisis and Fatwa Matters? Forum Riset Perbankan Syariah. Bank Indonesia \& Ikatan Ahli Ekonomi Islam Indonesia.

Al Arif, M.N.R. (2010). Efektivitas Biaya Promosi dan Biaya Diklat Terhadap Penghimpunan Dana Pihak Ketiga di Bank Syariah (Effectiveness of Promotion Cost and Training-Research Cost on Third Party Funds in Islamic Banks). Jurnal Ilmiah Ekonomi Bisnis. Vol. 15 (3): 175-182.

Al Arif, M. N. R. (2014). Spin-off and It's Impact on The Third Party Funds of Indonesian Islamic Banking Industry. Economic Journal of Emerging Markets. Vol. 6 (1): 50-55.

Al Arif, M.N.R. (2015). Keterkaitan Kebijakan Pemisahan Terhadap Tingkat Efisiensi Pada Industri Perbankan Syariah di Indonesia (The Relationship Between Spin-off Policy and Efficiency in The Indonesian Islamic Banking Industry). Jurnal Keuangan dan Perbankan. Vol. 19 (2): 295-304.

Amelia, E. (2015). Financial Ratio and Its Influence to Profitability in Islamic Banks. AlIqtishad: Journal of Islamic Economics. Vol. 7 (2): 229-240. 
Babar, H.Z. \& G. Zeb. (2011). Camels Rating System for Banking Industry in Pakistan. (Unpublished Master Thesis). Pakistan: Umea School of Business.

Chapra, M.U. (1985). Towards a Just Monetary System. London: Islamic Foundation.

Chapra, U.M. \& T. Khan. (2000). Regulation and Supervision of Islamic Banks. Jeddah: Islamic Research and Training Institute, IDB.

Choudhury, M. A. (2007). Development of Islamic economic and social thought. In Hassan, M. K \& M. K. Lewis (ed). Handbook of Islamic Banking. Cheltenham: Edward Elgar.

El-Hawary, D., W. Grais \& Z. Iqbal. (2004). Regulating Islamic Financial Institutions: The Nature of the Regulated. Working Paper. World Bank.

Hasbi, H. \& T. Haruman. (2011). Banking: According to Islamic Sharia Concepts and Its Performance in Indonesia. International Review of Business Research Paper. Vol. 7, No.1 : 60-76.

Ismal, Rifki. (2009). Performance of the Islamic Banking Industry. The original this paper was published in the Journal of Islamic Banking and Finance, Vol. 26 (2): $71-80$.

Ismal, R. (2011). Islamic Banking in Indonesia: Lessons to be Learned. United Nations of Conferences on Trade and Development, April 6th-8th, 2011.

Muljawan, D. (2005). A Design for Islamic Banking Rating System: An Integrated Approach. Working Paper. Bank of Indonesia.

Rahajeng, D. (2013). The role of Islamic Banking System as The Milestone Towards Indonesia Micro Economy Development: a Financial Report Approach. Munich Personal RePEc Archive. https://mpra.ub.uni-muenchen.de/50465/1/MPRA paper 50465.pdf. Accesed at January 2, 2017

Rusydiana, A.S. (2016). Analisis Masalah Pengembangan Perbankan Syariah di Indonesia: Aplikasi Metode Analytic Network Process (The Development Problems Analysis of Islamic Banking in Indonesia: Application of Analytic Network Process Method). Esensi: Jurnal Bisnis dan Manajemen. Vol. 6 (2): 237246.

Sari, I.M., H. Wibowo, \& E. Suprapto. (2015). Factors That Influenced People to Become Islamic Bank Customer: A Study on Kancana Villagers. Al-Iqtishad: Journal of Islamic Economics. Vol. 7 (1): 73-86. 
Performance of Depositor Funds

Sayakhmad Olimov, Abdul Hamid, M Arief Mufraini

Sari, M.D., Z. Bahari, Z. Hamat. (2016). History of Islamic Banking in Indonesia: Issues Behind Its Establishment. International Journal of Finance and Banking Research. Vol. 2 (5): 178-184.

Sarker, A.A. (2010). CAMELS Rating System in the Context of Islamic Banking: A Proposed 'S' for Shariah Framework. Journal of Islamic Economics, Banking, and Finance. Vol. 2 (2): 101-110.

Usman, H. (2015). The Role of Religious Norms on Selecting The Islamic Bank. AlIqtishad: Journal of Islamic Economics. Vol. 7 (1): 31-44. 